\title{
Effect of dimming of global radiation on morphology and yield of wheat crop in Delhi
}

\author{
BRIJESH YADAV, JOYDEEP MUKHERJEE, V.K. SEHGAL, D.K. DAS and PRAMEELA KRISHNAN \\ Division of Agricultural Physics, ICAR-Indian Agricultural Research Institute, New Delhi 110012, India \\ email:mjoydeep2k@yahoo.com
}

\begin{abstract}
Long-term observations of the surface global solar radiation in recent decades have shown a widespread declining trend in many parts of the world. Experient was carried out at the farm of ICARIndian Agricultural Research Institute, New Delhi during rabi season of 2014-15 and 2015-16 to study response of three cultivars (HD 2967, WR 544 and PBW 502) of wheat under five reduced solar radiation levels $(0,20,35,50,75 \%$ shading). Plant height, internode distance and leaf area index (LAI) were measured at different DAS throughout the crop growth period. The result shows that plant height and internode distance increased under $75 \%$ shading treatment. The highest leaf area index (LAI) was observed in $35 \%$ shading treatment, followed by $20 \%$ shading and control. Final biomass, grain yield and harvest index decreased significantly with shading and was lowest in $75 \%$ shading treatment. Among the cultivars, HD 2967 performed better under reduced radiation condition as compared to other cultivars.
\end{abstract}

Key words: Wheat, radiation, shading, yield, internode, harvest index

Solar radiation is the primary energy source for plant life which determines the crop growth and development. It plays an important role in many plant physiological and biochemical processes like chlorophyll synthesis, enzyme activation, photosynthesis that regulating the growth and development of plants. Apart from global warming, global dimming has received prominent attention because it causes climatic and environmental implications. As a consequence of increase in aerosol content, cloud cover and air pollutants, light dimming or reduction in global radiation have become major challenges for crop production (Mu et al., 2010). Long-term observations of the surface global solar radiation in recent decades have shown a widespread declining trend in many parts of the world (Liepert, 2002). Stanhill and Cohen (2001) reported averaged globally reduction of 0.51 $\mathrm{W} \mathrm{m}^{-2}$, or 2.7 per cent decade, since last 50 years. Liepert (2002) also observed $19 \mathrm{Wm}^{-2}$ or 10 per cent decline in surface solar radiation in the United States from 1961 to 1990. India also shows a continuous and steady light dimming since 1960s (Ramanathan et al., 2005; Mukherjee et al., 2014 and 2015).

Plant growth and development is adversely affected by reduced light intensity due to shading. Radiation interception, temperature, humidity and wind profile under reduced light condition are determining factor for wheat growth and yield and also the way through which these micrometeorological parameters alters the crop phenology, leaf area index, biomass production, RUE and grain yield (Healey et al., 1998). Keeping in view the importance of radiation dimming, the present study was undertaken to quantify the effect of global radiation dimming, on morphology and yield of wheat crop in Delhi, NCR region of India.

\section{MATERIALS AND METHODS}

A field experiment was conducted at research farm of Indian Agricultural Research Institute (IARI), New Delhi $\left(28^{\circ} 37^{\prime}\right.$ N latitude, $77^{\circ} 09^{\prime} \mathrm{E}$ longitude and altitude of 228.16 $m$ above mean sea level) during two consecutive rabi season (2014-15 and 2015-16). The soil of experimental site was sandy loam having $\mathrm{pH} 7.3$, organic carbon 0.47 per cent, available nitrogen $170.6 \mathrm{~kg} \mathrm{ha}^{-1}$, available phosphorus 18.6 $\mathrm{kg} \mathrm{ha}^{-1}$ and available potassium $275.0 \mathrm{~kg} \mathrm{ha}^{-1}$. Three wheat varieties of wheat (HD 2967, WR 544 and PBW 502) were sown on $25^{\text {th }}$ November and $21^{\text {th }}$ November in 2014-15 and 2015-16, respectively. A dose of 120:60:60 kg ha-1 of N:P:K was applied (three split dose of $\mathrm{N}$ as basal, CRI and flowering). Five solar radiation reduction treatments i.e. R1 (control), R2 (20\% shading), R3 (35\% shading), R4 (50\% shading) and R5 (75\% shading) were applied from tillering stage to maturity. Shading nets were installed on $13^{\text {th }}$ January and $10^{\text {th }}$ January for the year 2014-15 and 2015-16, respectively after tillering stage. 
Table 1: Mean global solar radiation under various radiation reduction levels at different DAS during the wheat growing season of $2014-15$ and $2015-16$

\begin{tabular}{|c|c|c|c|c|c|c|c|c|}
\hline Treatments & $36 \mathrm{DAS}$ & $42 \mathrm{DAS}$ & $61 \mathrm{DAS}$ & $82 \mathrm{DAS}$ & 86 DAS & $101 \mathrm{DAS}$ & $110 \mathrm{DAS}$ & $128 \mathrm{DAS}$ \\
\hline \multicolumn{9}{|c|}{ Radiation levels (\% shading) } \\
\hline $\mathrm{R} 1(0 \%)$ & 478.3 & 567.9 & 584.3 & 580.0 & 619.4 & 640.9 & 698.0 & 787.1 \\
\hline R2 (20\%) & 362.2 & 437.0 & 471.5 & 476.7 & 453.0 & 494.8 & 506.6 & 586.3 \\
\hline R3 (35\%) & 304.0 & 330.6 & 367.0 & 381.0 & 371.3 & 424.3 & 400.0 & 518.9 \\
\hline R4 (50\%) & 194.6 & 248.6 & 251.1 & 267.1 & 283.6 & 309.4 & 318.0 & 351.2 \\
\hline R5 (75\%) & 104.4 & 148.8 & 151.5 & 144.6 & 145.6 & 155.9 & 186.8 & 185.2 \\
\hline LSD at $5 \%$ & 14.85 & 20.30 & 36.30 & 31.70 & 39.40 & 21.25 & 28.40 & 29.40 \\
\hline $\mathrm{CV} \%$ & 4.7 & 5.2 & 9.1 & 7.8 & 9.6 & 4.8 & 6.1 & 5.5 \\
\hline \multicolumn{9}{|l|}{ Cultivars } \\
\hline HD 2967 & 293.5 & 342.0 & 356.5 & 375.5 & 375.3 & 405.3 & 421.7 & 482.0 \\
\hline WR 544 & 286.6 & 347.7 & 364.2 & 368 & 366.4 & 402.6 & 421.5 & 479.5 \\
\hline PBW 502 & 285.9 & 349.9 & 374.5 & 366.2 & 382 & 407.3 & 422.5 & 495.8 \\
\hline LSD at $5 \%$ & 3.5 & 7.7 & NS & NS & NS & NS & NS & 4.6 \\
\hline $\mathrm{CV} \%$ & 3.3 & 3.5 & 9.2 & 4.2 & 10.1 & 5.1 & 4.0 & 2.4 \\
\hline
\end{tabular}

Daily weather data were collected from the Agromet Observatory, IARI, New Delhi. Different radiation parameters such as global solar radiation was measured by pyranometer. Crop parameters like plant height, internode distance and leaf area index (by using canopy analyzer), were measured for each variety and each treatment at regular intervals throughout the crop growth period. Statistical analysis for split plot design were done by using online SAS package.

\section{RESULTS AND DISCUSSION}

\section{Radiation receipt under shade net}

The global solar radiation (Table 1) was significantly reduced in all the radiation reduction treatments (inside nets). The lowest global solar radiation $\left(151.5 \mathrm{~W} \mathrm{~m}^{-2}\right)$ was observed in R5 (75\% shading) as compared to $251.1 \mathrm{~W} \mathrm{~m}^{-}$ ${ }^{2}$ in R4 (50\% shading), $367.0 \mathrm{~W} \mathrm{~m}^{-2}$ in R3 (35\% shading) and $471.5 \mathrm{~W} \mathrm{~m}^{-2}$ in $\mathrm{R} 2$ (20\% shading) on 61 DAS. It was significantly reduced under R5 (75\% radiation reduction) in comparison with other treatments. Similar trend was observed at 110 and 128 DAS.

\section{Leaf area index (LAI)}

Mean leaf area index (LAI) under different solar radiation reduction levels and cultivars differed significantly (Table 2). LAI increased during vegetative phase and reached a peak around 86 DAS and decreased thereafter due to senescence in both the crop seasons. In case of different shading levels, at early vegetative stage the LAI showed non-significant variation up to 36 DAS but showed significant variation thereafter. The highest LAI (5.7) was observed in R3 (35\% shading), followed by 5.6 in R2 (20\% shading), 5.3 in R1 ( $0 \%$ shading), 5.2 in R4 (50\% shading) and 4.9 in R5 (75\% shading) at 86 DAS. Increasing leaf area may be due to crop was trying to maintain the growth under reduced light by allocating more photosynthates. Lakshmanakumar et al. (2015) also reported that LAI was more under severe shading than mild shading and open condition in wheat in Pantnagar condition. HD 2967 showed the highest LAI of 5.8, followed by WR 544 (5.3) and PBW 502 (5.1) at 86 DAS. Interaction effect between reduced radiation level and cultivars was significant at 10,110 and 128 DAS but other stages were non-significant.

\section{Plant height}

The plant height at 83 DAS differed significantly due to radiation level and cultivars. Plant height increased with increase in shading but the differences were non-significant at 96 and 110 DAS (Table 3 ). In case of cultivars, significant differences were observed at all the three dates of observations. HD 2967 showed the highest plant height of $104.1 \mathrm{~cm}$, followed by WR $544(98.5 \mathrm{~cm})$ and PBW 502 $(92.5 \mathrm{~cm})$ at 110 DAS. Similar type of results was also reported by Mina et al. (2015). The increase of plant height is due to allocation of photosynthates to stem and leaves to compensate less solar radiation. 
Table 2: Mean leaf area index (LAI) of wheat crop under various radiation reduction levels at different DAS during the wheat growing season of 2014-15 and 2015-16

\begin{tabular}{|c|c|c|c|c|c|c|c|c|}
\hline Treatments & $36 \mathrm{DAS}$ & $42 \mathrm{DAS}$ & $61 \mathrm{DAS}$ & $82 \mathrm{DAS}$ & 86 DAS & $101 \mathrm{DAS}$ & $110 \mathrm{DAS}$ & $128 \mathrm{DAS}$ \\
\hline \multicolumn{9}{|c|}{ Radiation levels (\% shading) } \\
\hline $\mathrm{R} 1(0 \%)$ & 1.1 & 1.5 & 3.2 & 3.9 & 5.3 & 3.8 & 3.4 & 2.7 \\
\hline R2 $(20 \%)$ & 1.3 & 1.5 & 3.3 & 4.5 & 5.6 & 4.0 & 3.3 & 2.5 \\
\hline R3 $(35 \%)$ & 1.2 & 1.7 & 3.5 & 4.6 & 5.7 & 4.5 & 3.8 & 2.4 \\
\hline R4 (50\%) & 1.1 & 1.5 & 3.1 & 3.5 & 5.2 & 4.2 & 2.7 & 2.0 \\
\hline R5 (75\%) & 1 & 1.3 & 3.2 & 3.5 & 4.9 & 3.7 & 2.3 & 2.1 \\
\hline LSD at $5 \%$ & NS & NS & 0.2 & 0.40 & 0.35 & 0.15 & 0.14 & 0.2 \\
\hline $\mathrm{CV} \%$ & 18.3 & 25.6 & 5.7 & 9.2 & 6.1 & 3.4 & 3.4 & 5.8 \\
\hline \multicolumn{9}{|l|}{ Cultivars } \\
\hline HD 2967 & 1.3 & 1.7 & 3.5 & 4.3 & 5.8 & 4.5 & 3.6 & 2.6 \\
\hline WR 544 & 1.1 & 1.5 & 3.3 & 4.1 & 5.3 & 4.0 & 3.1 & 2.3 \\
\hline PBW 502 & 1.0 & 1.3 & 3.0 & 3.7 & 5.1 & 3.6 & 2.8 & 2.1 \\
\hline LSD at $5 \%$ & 0.12 & 0.15 & 0.19 & 0.21 & 0.17 & 0.14 & 0.17 & 0.21 \\
\hline $\mathrm{CV} \%$ & 14.3 & 13.2 & 7.6 & 6.8 & 4.3 & 4.7 & 6.9 & 11.7 \\
\hline
\end{tabular}

Table 3: Mean plant height $(\mathrm{cm})$ of wheat crop under various radiation reduction levels at different DAS during the wheat growing season of 2014-15 and 2015-16

\begin{tabular}{lrrr}
\hline Treatments & 83 DAS & 96 DAS & 110 DAS \\
\hline \multicolumn{2}{l}{ Radiation levels (\% shading) } & & \\
R1 (0\%) & 67.4 & 90.6 & 95.9 \\
R2 (20\%) & 71.9 & 93.9 & 96.4 \\
R3 (35\%) & 80.5 & 94.9 & 98.5 \\
R4 (50\%) & 85.8 & 95.2 & 99.4 \\
R5 (75\%) & 88.5 & 96.5 & 100.7 \\
LSD at 5\% & 6.8 & $\mathrm{NS}$ & $\mathrm{NS}$ \\
CV\% & 5.7 & 4.8 & 3.0 \\
Cultivars & & & \\
HD 2967 & 79.9 & 100.0 & 104.1 \\
WR 544 & 85.3 & 96.3 & 98.5 \\
PBW 502 & 71.2 & 85.0 & 92.5 \\
LSD at 5\% & 4.6 & 3.8 & 2.6 \\
CV\% & 12.4 & 5.2 & 3.5 \\
\hline
\end{tabular}

\section{Internode distance}

Mean internode distance of wheat cultivars first, second, third, fourth and fifth internode from top to downwards in wheat crop at 85 DAS was significantly influenced by the various levels of reduced radiation (Table 4). It also shows that the internode length was maximum in second internode compared to other internodes.

The highest second internode length $(14.2 \mathrm{~cm})$ was observed in R5 (75\% shading) followed by $13.2 \mathrm{~cm}$ in R4 (50\% shading) and $12.3 \mathrm{~cm}$ in R3 (35\% shading). Similar trends were observed at 115 DAS. The first internode length was more as 115 DAS compared to 85 DAS. Among cultivars, the highest internode length was observed for HD 2967, followed by WR 544 and PBW 5 on both the observational days i.e. 85 and 115 DAS. Cruz-Aguado et al. (2000) reported that the internodes length of wheat significantly increased among different cultivars of wheat due to reduced solar radiation than open condition. In shading the increase of first internode i.e peduncle was obvious than the lower internodes (Lakshmanakumar et al., 2015).

\section{Biomass, grain yield and harvest index}

Grain yield, final biomass and harvest index were significantly reduced under R5 ( $75 \%$ shading) as compared to R4 (50\% shading), R3 (35\% shading), R2 (20\% shading) and R1 (control) condition (Table 5). Final biomass was lowest $\left(4.7 \mathrm{tha}^{-1}\right)$ in R5 and highest in R1 (13.5 tha $\left.\mathrm{t}^{-1}\right)$. Final biomass was also differed significantly in all three cultivars. Grain yield under R5 was only $0.7 \mathrm{tha}^{-1}$ while under $\mathrm{R} 1$ it was $4.6 \mathrm{tha}^{-1}$. Magnitude of yield reduction was slightly higher compared to solar radiation reduction inside shades. Average grain yield reduction was $81 \%, 68 \%, 48 \%$ and $23 \%$ under R5, R4, R3 and R2 treatments, respectively in 2014-15 but magnitude was higher during $2015-16$ i.e. $88 \%, 74 \%, 58 \%$, 
Table 4: Mean internode length $(\mathrm{cm})$ from top to down in wheat crop under various radiation reduction levels on 85 DAS and 115 DAS during the growing season 2014-15 and 2015-16.

\begin{tabular}{|c|c|c|c|c|c|c|c|c|c|c|}
\hline \multirow[t]{2}{*}{ Treatments } & \multicolumn{5}{|c|}{$85 \mathrm{DAS}$} & \multicolumn{5}{|c|}{$115 \mathrm{DAS}$} \\
\hline & $1 \mathrm{st}$ & 2nd & $3 \mathrm{rd}$ & 4 th & 5 th & $1 \mathrm{st}$ & $2 \mathrm{nd}$ & $3 \mathrm{rd}$ & 4 th & 5 th \\
\hline \multicolumn{11}{|c|}{ Radiation levels (\% shading) } \\
\hline $\mathrm{R} 1(0 \%)$ & 9.20 & 10.5 & 10.2 & 8.30 & 5.5 & 24.9 & 15.2 & 10.9 & 8.80 & 5.6 \\
\hline R2 (20\%) & 9.80 & 11.3 & 10.8 & 8.90 & 5.8 & 25.8 & 16.1 & 12.3 & 9.30 & 6.0 \\
\hline R3 (35\%) & 10.4 & 12.3 & 11.3 & 10.1 & 6.2 & 26.7 & 17.3 & 13.4 & 10.2 & 6.3 \\
\hline $\mathrm{R} 4(50 \%)$ & 11.2 & 13.2 & 12.0 & 9.70 & 6.5 & 27.9 & 18.3 & 14.3 & 11.1 & 6.8 \\
\hline R5 (75\%) & 12.3 & 14.2 & 12.7 & 10.3 & 6.9 & 29.3 & 19.0 & 16.0 & 11.8 & 7.1 \\
\hline $\operatorname{LSD}(5 \%)$ & 0.3 & 0.2 & 0.3 & 0.3 & 0.1 & 0.6 & 0.5 & 0.3 & 0.5 & NS \\
\hline \multicolumn{11}{|l|}{ Cultivars } \\
\hline HD 2967 & 12.4 & 15.3 & 13.3 & 10.4 & 7.3 & 32.1 & 17.8 & 15.8 & 11.8 & 7.7 \\
\hline WR 544 & 11.6 & 13.5 & 12.3 & 9.80 & 6.7 & 30.0 & 16.5 & 14.1 & 10.8 & 7.0 \\
\hline PBW 502 & 11.1 & 12.9 & 11.2 & 9.50 & 6.1 & 28.4 & 14.9 & 13.0 & 9.90 & 6.5 \\
\hline $\operatorname{LSD}(5 \%)$ & 0.36 & 0.45 & 0.44 & 0.38 & 0.42 & 0.95 & 1.1.0 & 0.85 & 0.60 & NS \\
\hline CV (\%) & 3.3 & 4.2 & 4.2 & 4.6 & 5.2 & 4.4 & 5.1 & 5.5 & 5.3 & 4.7 \\
\hline
\end{tabular}

Table 5: Variation of mean grain yield, final biomass and harvest index in wheat as influenced by different radiation reduction levels during the growing season 2014-15 and 2015-16.

\begin{tabular}{lrrr}
\hline Treatments & $\begin{array}{r}\text { Final biomass } \\
\left(\mathrm{t} \mathrm{ha}^{-1}\right)\end{array}$ & $\begin{array}{r}\text { Grain yield } \\
\left(\mathrm{t} \mathrm{ha}^{-1}\right)\end{array}$ & $\begin{array}{r}\mathrm{HI} \\
(\%)\end{array}$ \\
\hline Radiation levels (\% shading) & & \\
R1 (0\%) & 13.5 & 4.6 & 33.5 \\
R2 (20\%) & 11.2 & 3.3 & 29.0 \\
R3 (35\%) & 8.5 & 2.2 & 24.9 \\
R4 (50\%) & 7.3 & 1.5 & 17.8 \\
R5 (75\%) & 4.7 & 0.7 & 14.6 \\
LSD at 5\% & 0.9 & 0.4 & 4.1 \\
CV\% & 9.4 & 12.7 & 15.7 \\
Cultivars & & & \\
HD 2967 & 10.2 & 3.0 & 27.9 \\
WR 544 & 8.9 & 2.4 & 23.9 \\
PBW 502 & 7.9 & 1.8 & 20.1 \\
LSD at 5\% & 0.6 & 0.2 & 2.1 \\
CV\% & 8.9 & 9.1 & 11.4 \\
\hline
\end{tabular}

and $34 \%$ in R5, R4, R3 and R2, respectively. Similar findings have been also reported by Lakshmanakumar et al., (2015) and Mu et al., (2010). Grain yield also differed significantly in all three cultivars. Cultivar HD 2967 showed higher grain yield $\left(3.0 \mathrm{t} \mathrm{ha}^{-1}\right)$ in all treatments as compared to WR 544 (2.4 $\left.\mathrm{t} \mathrm{ha}^{-1}\right)$ and PBW $502\left(1.8 \mathrm{tha}^{-1}\right)$. Harvest index was lowest under R5 (14.6\%), followed by R4 (17.8\%) and R3 (24.9\%) and highest under open condition (33.5\%). Non-significant interaction effect between reduced radiation level and cultivars was found during 2014-15 but grain yield and harvest index were significantly different during 2015-16 except final biomass.

\section{CONCLUSION}

Reduced solar radiation adversely affects the plant growth and yield of wheat. Final biomass, grain yield and harvest index were significantly decreased whereas, plant height and internode length were significantly increased with shading. LAI was also significantly affected under low irradiance. The impact of light dimming was less in cultivar HD 2967 as compared to WR 544 and PBW 502.This research might be helpful for farmers in selecting suitable cultivar and for breeders to develop new varieties to increase agricultural productivity under light dimming condition.

\section{REFERENCES}

Cruz-Aguado, J.A., Rodés, R., Pérez, I.P. and Dorado, M. (2000). Morphological characteristics and yield components associated with accumulation and loss of dry mass in the internodes of wheat. Field Crops Res., 66(2):129-139. 
Healey, K.D., Rickert, K.G., Hammer, G.L. and Bange, M.P. (1998). Radiation use efficiency increases when the diffuse component of incident radiation is enhanced under shade. Australian J. Agri. Res., 49: 665-672.

Lakshmanakumar, P., Bana, O.P.S. and Guru, S. K. (2015). Morphological and physiological characteristics of wheat (Triticum aestivum L.) under different light condition. Intern. Res. J. Natural Applied Sci., 2(4): 2349-4077.

Liepert, B. G. (2002). Observed reductions of surface solar radiation at sites in the United States and worldwide from 1961 to 1990. Geophy. Res. Letters, 29(10):1421.

Mina, U., Singh, S. D., Singh, B. and Khaund, M. (2015). Response of wheat and chickpea cultivars to reduced levels of solar irradiance. J. Agrometeorol., 17(2): 165171.

Mu, H., Jiang, D., Wollenweber, B., Dai, T., Jing, Q. and Cao, W. (2010). Long term low radiation decreases leaf photosynthesis, photochemical efficiency and grain yield in winter wheat. J. Agron. Crop Sci., 196:38-47.
Mukherjee, J., Singh, G. and Bal, S. K. (2014). Radiation use efficiency and instantaneous photosynthesis at different growth stages of wheat (Triticum aestivum L.) in semi arid ecosystem of Central Punjab, India. $J$. Agrometeorol., 16(1): 69-77.

Mukherjee, Joydeep, S.S. Singh, Santosh Kumar and Mohd. Idris. (2015). Radiation use efficiency and yield of wheat crop grown under elevated $\mathrm{CO}_{2}$ and temperature in open top chamber in Patna, Bihar. J. Agrometeorol.,17(2): 158-164.

Ramanathan, V., Chung, C., Kim, D., Bettge, T., Buja, L., Kiehl, J. T. and Wild, M. (2005). Atmospheric brown clouds: Impacts on South Asian climate and hydrological cycle. Proc. National Acad. Sci. USA., 102(15): 53265333.

Stanhill, G. and Cohen, S. (2001). Global dimming: a review of the evidence for a widespread and significant reduction in global radiation with discussion of its probable causes and possible agricultural consequences. Agric. Forest Meteorol., 107(4): 255-278. 